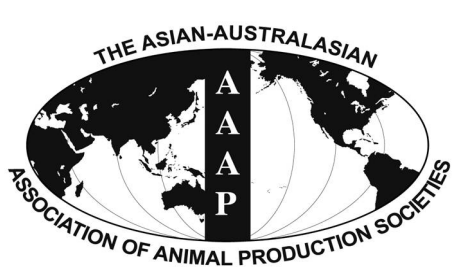

Open Access

Asian Australas. J. Anim. Sci.

Vol. 29, No. 1 : 23-28 January 2016

http://dx.doi.org/10.5713/ajas.14.0812

www.ajas.info

pISSN 1011-2367 elSSN 1976-5517

\title{
Identification of Single Nucleotide Polymorphism Marker and Association Analysis of Marbling Score in Fas Gene of Hanwoo
}

\author{
Seung-Chang Kim, Seung-Hwan Lee, Ji-Woong Lee ${ }^{1, *}$, Tae-Hun Kim, and Bong-Hwan Choi* \\ Division of Animal Genomics and Bioinformatics, National Institute of Animal Science, \\ Rural Development Administration, Wanju 565-851, Korea
}

\begin{abstract}
The Fas (APO-1, TNFRSF6) gene known as a member of the tumor necrosis factor receptor superfamily was selected for DNA marker development in Korean cattle. It is a cell membrane protein and mediates programmed cell death (apoptosis). We discovered single nucleotide polymorphisms (SNPs) within Fas gene in order to develop novel DNA markers related to economical traits at the genomic level. The sequences of whole exon and $1 \mathrm{~kb}$ range of both front and back of the gene were determined by directsequencing methods using 24 cattle. A total of 55 SNPs were discovered and we selected 31 common polymorphic sites considering their allele frequencies, haplotype-tagging status and linkage disequilibrium (LD) for genotyping in larger-scale subjects. The SNPs were confirmed genotype through the SNaPshot method $(n=274)$ and were examined for a possible genetic association between Fas polymorphisms and marbling score. So, the SNPs that were identified significant are g.30256G $>$ C, g.31474C $>$ A, g.31940A $>$ G, and g.32982G>A. These results suggest that SNPs of Fas gene were associated with intramuscular fat content of meat quality traits in Korean cattle. (Key Words: Fas, Hanwoo, Linkage Disequilibrium, Marbling Score, Single Nucleotide Polymorphism)
\end{abstract}

\section{INTRODUCTION}

Marbling is one of the most important factors determining the grade of beef in the United States (USDA, 1989), Japan (JMGA, 1988), and South Korea, as well as having an effect on tenderness and juiciness. Therefore, various studies for improving intramuscular fat, such as extending period of fattening or high-energy feeding programs have been conducted in beef. However, these methods led to not only to the improvement of intramuscular fat but also to an increase of backfat and visceral fat in beef production. So, this undesirable consequence has progressed many studies to detect Quantitative trait loci (QTL) associated with economic

\footnotetext{
* Corresponding Authors: Ji-Woong Lee. Tel: +82-62-530-2111, E-mail: jwlee@jnu.ac.kr / Bong-Hwan Choi. Tel: +82-31-2901592, Fax: +82-31-290-1792, E-mail: bhchoi@korea.kr

${ }^{1}$ Devision of Animal Science, Institute of Agricultural Science and Technology, Chonnam National University, Gwangju 500757 , Korea.

Submitted Oct. 18, 2014; Revised Dec. 2, 2014; Accepted Jun. 15, 2015
}

traits for improvement of livestock through marker selection of superior cattle. This method selects DNA markers related to phenotype based on genetic value and statistical significance through association analysis between genetic variation and phenotype after identification of the genetic variation structure at each object. Then, the validated DNA marker can be used for Marker-Assisted Selection (MAS) (Lande and Thompson, 1990; Darvasi and Soller, 1994). In particular, single nucleotide polymorphisms (SNP) have been used to identify genetic markers for useful economic traits.

Direct sequencing of PCR (polymerase chain reaction) products have typically been applied to the identification of various gene mutations. However, with large numbers of samples, these approaches are time consuming and/or expensive. Primer extension assays have been developed for several genes with common mutations. SNaPshot is a commercially available kit for the multiplex detection of SNPs that relies on the extension of a primer annealed immediately adjacent to the SNP of interest, using fluorescently labeled dideoxynucleotides (ddNTPs). Each 
fluorescent ddNTP emits a different wavelength that is translated into a specific color for each base. The fluorescent labeled extension products can be visualized by electrophoresis using a capillary automated sequencer (Quintans et al., 2004).

Fas is a single polypeptide transmembrane protein that mediates apoptosis in a variety of hematopoietic, fibroblastic and malignant cells (Itoh et al., 1991; Oehm et al., 1992; Watanabe-Fukunaga et al., 1992). It was first recognized as an apoptosis inducer when activated human lymphocytes and certain cell lines underwent apoptosis upon exposure to monoclonal anti-Fas antibodies (Trauth et al., 1989; Yonehara et al., 1989). Molecular cloning of human and mouse Fas cDNAs demonstrated that it belongs to the tumor necrosis factor receptor (TNFR) superfamily, which includes the low-affinity nerve growth factor receptor (NGFR), TNFR types I and II, human B-cell antigen CD40, T-cell antigen CD27, and OX40 (Johnson et al., 1986; Stamenkovic et al., 1989; Loetscher et al., 1990; Mallett et al., 1990; Schall et al., 1990; Camerini et al., 1991).

In previous study, it found that Fas was negatively correlated to intramuscular fat content in the $m$. longissimus tissue of Korean cattle. HSPB1 expression in both mRNA and protein was shown to be negatively related to intramuscular fat content and was regulated by FAS and angiotensinogen. It suggests that the Fas gene may be one of the $258 \mathrm{key}$ genes controlling adipogenesis through a mitogen-activated protein kinases signaling pathway. Therefore, Fas protein play an important role in the trait expression associated with fat synthesis (Kim et al., 2011). The objective of this study was to discover SNPs of the Fas gene located within QTL regions related to meat quality trait and to identify association with each SNP and marbling score (MS) traits in Hanwoo.

\section{MATERIALS AND METHODS}

\section{Animals and phenotypes}

Phenotype data and blood samples for SNP marker genotyping were obtained from 274 steers descending from 76 sires and unrelated dams from Hanwoo progeny-tested steers at Livestock Improvement Main Center. The Hanwoo received a total mixed diet of concentrate and rice straw with a ratio in total feed of about 1.5:1, 2:1, and 4.5:1 for growing period (4 to 12 months), finishing period I (13 to 18 months) and finishing period II (19 to 24 months), respectively for ad libitum intake. Crude protein and total digestible nutrients of the concentrate were $14 \%-16 \%, 11 \%$ $13 \%$ and $11 \%$ and $68 \%$ to $70 \%, 71 \%$ to $73 \%$, and $72 \%$ to $73 \%$ for growing period, finishing period I and finishing period II, respectively. Phenotypic data in this study included carcass weight (CWT), eye muscle area (EMA), back fat thickness (BF) and MS. The BF, EMA, and MS were measured at the 12th to 13 th rib junction after a 24 hour chill. The statistics for phenotypic data is summarized in Table 1. Marbling score was assessed on a 1 to 7 scale, and the degree of marbling was evaluated based on the Korean Beef Marbling Standard (BMS) from Animal Product Grading Service in Korea (APGS, 1995). Genomic DNA was separated from blood of cattle following modified salting out method (Miller et al., 1988). DNA was quantified using the NanoDrop ND-1000 Spectrophotometer (NanoDrop Technology). DNA samples were diluted to $10 \mathrm{ng} / \mu \mathrm{L}$ and were stored at $-20^{\circ} \mathrm{C}$.

\section{Sequencing and SNP analysis}

SNP identification in Fas gene was used for 24 different cattle having a different grandsire and sire. Primers for the sequence determination were produced to be about 700bp of PCR product using primer3 software (http://wwwgenome.wi.mit.edu/cgi-bin/primer3-www.results.cgiv) based on genetic information (BC140650.1) registered in the NCBI GenBank. Primers were selected for amplification of exon 7 (ex7-Fw 5'-CAAAATCAGGACAAATAGGCTT CT-3'; ex7-Rv 5'-TGTTGGAAAAAGATATGGTGACAG3'), exon 8 (ex8-Fw 5'-AATTTGAATGGTGAAAGAA TCCTC-3'; ex8-Rv 5'-TCTTATCCCAGCTCCTTCTAT GTC-3') and exon 9 (ex9a-Fw 5'-GATAAGATGGTCATAA ACCCTTGG-3'; ex9a-Rv 5'-AAGAAAACACACCCAGT AAAAAGC-3'; ex9b-Fw 5'-TCTTGCAGAGAAAATTTG TGACAT; ex9b-Rv 5'-CACCTGAGAAAGAAGTGGG TTATT-3'), with the amplicons covering position of 30,256, $31,474,31,940$, and 32,982.

PCR was performed in $20 \mu \mathrm{L}$ volumes, each containing $50 \mathrm{ng}$ of genomic DNA, $2 \mu \mathrm{L}$ of $10 \times$ buffer $(100 \mathrm{mM}$ Tris $\mathrm{pH} 8.9,50 \mathrm{mM} \mathrm{KCl}, 15 \mathrm{mM} \mathrm{MgCl}, 0.01 \%$ gelatin, $0.1 \%$ Triton X-100, $10 \mathrm{mg} / \mathrm{mL}$ bovine serum albumin), $0.5 \mu \mathrm{L}$ of each primer $(10 \mathrm{pmol}), 1 \mu \mathrm{L}$ of dNTPs $(20 \mathrm{mM})$ and 0.5 unit of Hot Start Taq DNA polymerase (GeNet Bio, Daejeon, Korea). PCR conditions were $94^{\circ} \mathrm{C}$ for $5 \mathrm{~min}$ and 35 cycles of $30 \mathrm{~s}$ at $94^{\circ} \mathrm{C}, 30 \mathrm{~s}$ at $60^{\circ} \mathrm{C}, 1 \mathrm{~min}$ at $72^{\circ} \mathrm{C}$, and a final step of $10 \mathrm{~min}$ at $72^{\circ} \mathrm{C}$ using a Tetrad 2 Peltier

Table 1. Means, standard deviation (SD) and extreme value of the phenotypes measured on carcass traits in Hanwoo

\begin{tabular}{lcccc}
\hline Traits & Mean & SD & Minimum & Maximum \\
\hline LWT $(\mathrm{kg})$ & 546.2 & 54.93 & 320.0 & 710.0 \\
CWT $(\mathrm{kg})$ & 321.7 & 34.45 & 174.0 & 423.0 \\
DP $(\%)$ & 58.89 & 2.081 & 54.18 & 58.89 \\
EMA $\left(\mathrm{cm}^{2}\right)$ & 74.20 & 8.569 & 30.00 & 99.00 \\
BF $(\mathrm{cm})$ & 8.161 & 3.041 & 3.000 & 21.00 \\
MS $(1-7)$ & 1.814 & 1.099 & 1.000 & 7.000 \\
\hline
\end{tabular}

LWT, live weight; CWT, carcass weight; DP, dressing percentage; EMA, eye muscle area; BF, backfat thickness; MS, marbling score. 
Thermal Cycler (Bio-Rad, Hercules, CA, USA). PCR product identified on $1.5 \%$ agarose gel was filtered by MultiScreen filter plates (Millipore, Billerica, MA, USA). Then PCR was performed in $10 \mu \mathrm{L}$ volumes, each containing $2 \mu \mathrm{L}$ of Filtered PCR product, $1.75 \mu \mathrm{L}$ of $5 \times$ buffer ( $400 \mathrm{mM}$ tris, $10 \mathrm{mM} \mathrm{MgCl}$ ), $0.5 \mu \mathrm{L}$ of Big Dye and $1 \mu \mathrm{L}$ of each primer $(5 \mathrm{pmol})$. PCR conditions were $96^{\circ} \mathrm{C}$ for $10 \mathrm{~s}$ and 34 cycles of $5 \mathrm{~s}$ at $50^{\circ} \mathrm{C}, 4 \mathrm{~min}$ at $60^{\circ} \mathrm{C}$. PCR product was refined using alcohol after PCR and dried. Dried sample was added with $8 \mu \mathrm{L}$ of Hi-Di Formamide (Applied Biosystems, Waltham, MA, USA) and allowed to react for $2 \mathrm{~min}$ at $95^{\circ} \mathrm{C}$. Then, DNA sequence was analyzed on ABI 3730XL Genetic Analyzer (Applied Biosystems, USA). SNP was analyzed by the Lasergene software (Version 7, DNA Star, Madison, WI, USA).

\section{SNaPshot and genotyping}

SNaPshot probes were manually designed by checking their annealing temperature (Table 2). The length of a primer was modified by the addition of non-homologous polynucleotides at the 5' end. The primers for PCR and SNaPshot analysis were synthesized by Bioneers (Daejeon, Korea). The SNaPshot reaction was performed in a total volume of $5 \mu \mathrm{L}$ using $2 \mu \mathrm{L}$ of SNaPshot Mastermix, $2 \mu \mathrm{L}$ of primer and $1 \mu \mathrm{L}$ of filtered PCR product. Thermal cycling conditions were 25 cycles of $10 \mathrm{~s}$ at $96^{\circ} \mathrm{C}, 5 \mathrm{~s}$ at $55^{\circ} \mathrm{C}$ and $30 \mathrm{~s}$ at $60^{\circ} \mathrm{C}$. The SNaPshot products were then cleaned by adding $1 \mu \mathrm{L}$ of Shrimph alkaline phosphatase (SAP, Thermo Fisher, Waltham, MA, USA) and $1 \mathrm{~h}$ incubation at $37^{\circ} \mathrm{C}$, followed by a $15 \mathrm{~min}$ enzyme denaturation at $75^{\circ} \mathrm{C}$. Fragments were separated on an ABI 3730-Genetic Analyzer (Applied Biosystems) using $8.5 \mu \mathrm{L}$ of formamide, $0.5 \mu \mathrm{L}$ of GeneScan-120 LIZ size standard (Applied Biosystems) and $1 \mu \mathrm{L}$ of cleaned SNaPshot product. A 36 $\mathrm{cm}$ capillary array and the polymer POP-4 were used and the instrument settings were defaulted as recommended by the manufacturer. Raw data was analyzed using the Lasergene software (DNA Star, USA). Main data analysis was accomplished with a PHASE v2.1.1 and Haploxt software (University of Michigan, Ann Arbor, MI, USA).

\section{Statistical analyses}

Analysis of the statistical relevance with the phenotypic measurement and the four SNP genotype of Fas gene were evaluated with the mixed regression models using ASReml
3.0 program (Gilmour et al., 2006). Also, p-value less than 0.01 were accepted as statistically significant. The difference of mean value was performed a test of significance of difference of genotype through a Fisher's least significant difference test using the following statistical linear model:

$$
Y_{i j k}=\mu+Y S_{i}+b \cdot D_{i j k}+\text { Genotype }_{j}+A_{i j k}+e_{i j k}
$$

where $Y_{i j k}$ is the observation of the carcass traits, $\mu$ is the overall mean for each trait, $Y S_{i}$ is the effect of season, $b$ is convariation of slaughter age, $D_{i j k}$ is slaughter age (month), Genotype $e_{j}$ is the effect of genotype, $A_{i j k}$ is the fixed effect of individual and $e_{i j k}$ is the random residual effect.

\section{RESULTS AND DISCUSSION}

Marbling is generally considered to increase juiciness and tenderness of meat, and therefore to have a positive association with eating quality (Wood et al., 1995; Gutierrez-Gil et al., 2008). The marbling increase is an economically important trait of beef industry in Korea. A better knowledge of the molecular mechanism of marbling is important as it may generate new opportunities for more effective MAS, leading to economic benefits to the beef industry (Yamada et al., 2009). Recently, there have been many efforts to improve meat quality following the development of genomics using DNA markers in livestock (Maj et al., 2006; Otto et al., 2007; Gill et al., 2010).

The Fas gene, a member of the (TNF) receptor superfamily that mediates apoptosis in a various cells, was known to associate with intramuscular fat content from previous study (Kim et al., 2011). Fas gene has nine exons and is located at bovine chromosome 26 (BTA26) from AC_000183.1 (10714194..10748026, Bos_taurus_UMD_3.1). The sequences of whole exon and $1 \mathrm{~kb}$ range of both front and back of the gene were determined by PCR-direct sequencing using 24 different cattle each having a different grandsire and sire. The homology was more than $99 \%$ with sequence reported in GenBank (BC140650.1). It was selected SNP of locus having mutation frequency of 0.01 or more and nucleotide both homo- and hetero-type. The 55 SNPs were discovered. And, 33 polymorphic sites were selected considering their allele frequencies, haplotype-

Table 2. SNaPshot probes for the detection of Fas genotypes

\begin{tabular}{lllll}
\hline Probe & \multicolumn{1}{c}{ Sequence $\left(5^{\prime} \rightarrow 3^{\prime}\right)$} & Position & SNP & Size $(\mathrm{bp})$ \\
\hline SNP1 & $\mathrm{at}_{(10)}$ CCCCCTACTTGTTACTTTTTAAAAAGCAAAC & g.30256 & $\mathrm{G}>\mathrm{C}$ & 51 \\
SNP2 & CTGAATTGTAGACTCAGTTGTATACTTACTC & $\mathrm{g} .31474$ & $\mathrm{C}>\mathrm{A}$ & 31 \\
SNP3 & $\operatorname{ta}_{(8)}$ tAAAAGTGGGAATTTTGTTTAGAAAAACAAATTTTCAGA & $\mathrm{g} .31940$ & $\mathrm{~A}>\mathrm{G}$ & 55 \\
SNP4 & $\mathrm{ta}_{(8)}{ }^{\mathrm{tCAGACTCAGTTATAATGCTTGAATATTTTATATTTGTC}}$ & $\mathrm{g} .32982$ & $\mathrm{G}>\mathrm{A}$ & 55 \\
\hline
\end{tabular}

SNP, single nucleotide polymorphism. 


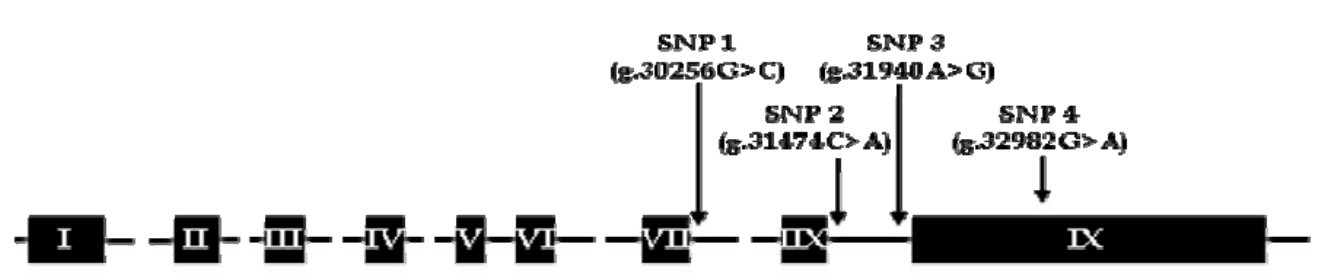

Figure 1. The positions of detected SNPs at tumor necrosis factor receptor superfamily member 6 (Fas) gene in Korean cattle (Hanwoo). SNPs, single nucleotide polymorphisms.

tagging status and linkage disequilibrium (LD) for genotyping of larger-scale subjects. The SNPs were confirmed genotype through SNaPshot method using 274 Hanwoo progeny-tested steers at Livestock Improvement Main Center and were examined for possible genetic association of Fas polymorphisms with MS. As a result, single locus association analysis for Fas gene found that four SNPs were associated with the meat quality trait. The SNPs in intron VII and IIX region and in exon IX region was identified (Figure 1). The four SNPs was verified by the dbSNP of GenBank. It was showed to be significant SNP of g.30256G $>$ C, g.31474C $>$ A, g.31940A $>$ G, and g.32982G $>$ A with MS $(\mathrm{p}<0.001)$ (Table 3$)$. In case of g.30256G $>$ C SNP identified significant association, the GC genotype was shown to be superior to the more than $\mathrm{CC}$ and GG genotypes. Similarly, g.31940A $>$ G and g.32928G $>$ A was shown to be superior to the GA genotype more than GG and AA genotypes. But at locus g.31474C $>$ A, Hanwoo with homozygous genotype AA showed a significantly higher marbling score compared with those of heterozygous genotype $\mathrm{CA}$ or homozygous genotype $\mathrm{CC}$. The results give strong evidence for the potential of MAS for marbling and could produce substantial improvement of meat quality traits in Hanwoo.

The three SNPs were located in intron region and one SNP was located in exon region. The intron SNPs do not regulate the function of the gene. Generally, introns are considered superfluous parts that must be removed to make a mature mRNA. However, it is known that they are facilitators of molecular evolution and regulators of gene expression. It was demonstrated in several systems, including mammalian tissue culture cells, transgenic mice, insects, and plants, that optimal expression of many endogenous genes similarly requires the presence of one or more introns (Callis et al., 1987; Buchman and Berg, 1988; Chiou et al., 1991; Palmiter et al., 1991; Duncker et al., 1997; Bourdon et al., 2001). And the nucleotide variation of introns in specific genes plays an important role in transcription and translation (Nott et al., 2003). The magnitude of intron-dependent effects can vary tremendously, from almost nothing to more than a 400-fold increase in mRNA levels (Buchman and Berg, 1988; Bourdon et al., 2001).

Chromosomes such as BTA14 and BTA26 known to have exon regions linked to meat quality trait QTL are primary sites for the presence of functionally important genes affecting lipid metabolism (Casas et al., 2004; Marques et al., 2009). Especially, association studies of economic traits and SNPs have implicated many genes in the BTA26 QTL region (Taniguchi et al., 2004; Gautier et al., 2006). Therefore, it could be a LD effect with lipid metabolism-related genes associated with the QTL of each trait presenting around the Fas gene. A previous study reported that Fas gene was negatively correlated to intramuscular fat content (Kim et al., 2011). The Fas gene was thought to have an association with economic traits. The QTL associated with these traits may be LD markers. The bovine Fas gene in the BTA26 region appeared to be related to MS directly or indirectly or both in Hanwoo.

In summary, we identified 55 SNPs and selected 33 SNPs through haplotype-tagging status and LD analysis in Hanwoo Fas gene. Genotyping analysis and association analysis were performed on selected SNPs. Four SNPs were significantly associated with MS in economic traits. The meat quality grade in beef uses the BF, EMA, CWT, and MS having significant impact in quality of the cattle carcass.

Table 3. Least square means and standard errors of phenotypic measurements from carcass traits by Fas genotypes in Hanwoo

\begin{tabular}{|c|c|c|c|c|c|}
\hline Trait & Type & & Genotype & & $\mathrm{p}$ value \\
\hline \multirow{4}{*}{ Marbling score } & g. $30256 \mathrm{G}>\mathrm{C}$ & $\begin{array}{c}\mathrm{CC} \\
1.77 \pm 0.15\end{array}$ & $\begin{array}{c}\mathrm{GC} \\
2.08 \pm 0.13\end{array}$ & $\begin{array}{c}\mathrm{GG} \\
1.70 \pm 0.13\end{array}$ & $\mathrm{p}<0.001$ \\
\hline & g. $31474 C>A$ & $\begin{array}{c}\text { AA } \\
2.02 \pm 0.12\end{array}$ & $\begin{array}{c}\text { CA } \\
1.51 \pm 0.27\end{array}$ & $\begin{array}{c}\mathrm{CC} \\
1.676 \pm 0.17\end{array}$ & $\mathrm{p}<0.001$ \\
\hline & g. $31940 \mathrm{~A}>\mathrm{G}$ & $\begin{array}{c}\mathrm{GG} \\
1.77 \pm 0.14\end{array}$ & $\begin{array}{c}\text { GA } \\
2.04 \pm 0.12\end{array}$ & $\begin{array}{c}\mathrm{AA} \\
1.65 \pm 0.13\end{array}$ & $\mathrm{p}<0.001$ \\
\hline & g. $32982 \mathrm{G}>\mathrm{A}$ & $\begin{array}{c}\mathrm{AA} \\
1.68 \pm 0.16\end{array}$ & $\begin{array}{c}\text { GA } \\
2.04 \pm 0.12\end{array}$ & $\begin{array}{c}\mathrm{GG} \\
1.68 \pm 0.13\end{array}$ & $\mathrm{p}<0.001$ \\
\hline
\end{tabular}


Therefore, it was considered that the Fas gene could be used to improve the selection of Hanwoo. The goal of this study was to find information about molecular markers for MAS. The identification of the causative mutations accounting for the variability at these economic traits would be not only allow increased accuracy of selection but also allow focused genotyping of essential markers for selection of a specific trait. Further study will be necessary in larger populations to validate the use these SNP for MAS. It is also important to investigate whether the Fas gene plays a role in the development of these traits and whether it is involved in LD with other causative mutations.

\section{CONFLICT OF INTEREST}

We certify that there is no conflict of interest with any financial organization regarding the material discussed in the manuscript.

\section{ACKNOWLEDGMENTS}

This work was supported by the Cooperative Research Program for Agriculture Science \& Technology Development (Project No. PJ0087112014)" Rural Development Administration, Republic of Korea and by 2014 PostDoctoral Fellowship Program of National Institute of Animal Science, Rural Development Administration, Republic of Korea.

\section{REFERENCES}

APGS. 1995. Report of Business for Animal Products Grading. Animal Products Grading System, National Co-Operatives Federation, Korea.

Bourdon, V., A. Harvey, and D. M. Lonsdale. 2001. Introns and their positions affect the translational activity of mrna in plant cells. EMBO Rep. 2:394-398.

Buchman, A. R. and P. Berg. 1988. Comparison of introndependent and intron-independent gene expression. Mol. Cell Biol. 8:4395-4405.

Callis, J., M. Fromm, and V. Walbot. 1987. Introns increase gene expression in cultured maize cells. Genes Dev. 1:1183-1200.

Camerini, D., G. Walz, W. A. Loenen, J. Borst, and B. Seed. 1991. The $\mathrm{T}$ cell activation antigen $\mathrm{cd} 27$ is a member of the nerve growth factor/tumor necrosis factor receptor gene family. J Immunol. 147:3165-3169.

Casas, E., J. W. Keele, S. D. Shackelford, M. Koohmaraie, and R. T. Stone. 2004. Identification of quantitative trait loci for growth and carcass composition in cattle. Anim. Genet. 35:2-6.

Chiou, H. C., C. Dabrowski, and J. C. Alwine. 1991. Simian virus 40 late mRNA leader sequences involved in augmenting mRNA accumulation via multiple mechanisms, including increased polyadenylation efficiency. J. Virol. 65:6677-6685.

Darvasi, A. and M. Soller. 1994. Selective DNA pooling for determination of linkage between a molecular marker and a quantitative trait locus. Genetics 138:1365-1373.

Duncker, B. P., P. L. Davies, and V. K. Walker. 1997. Introns boost transgene expression in drosophila melanogaster. Mol. Gen. Genet. 254:291-296.

Gautier, M., R. R. Barcelona, S. Fritz, C. Grohs, T. Druet, D. Boichard, A. Eggen, and T. H. Meuwissen. 2006. Fine mapping and physical characterization of two linked quantitative trait loci affecting milk fat yield in dairy cattle on BTA26. Genetics 172:425-436.

Gill, J. L., S. C. Bishop, C. McCorquodale, J. L. Williams, and P. Wiener. 2010. Associations between single nucleotide polymorphisms in multiple candidate genes and carcass and meat quality traits in a commercial angus-cross population. Meat Sci. 86:985-993.

Gilmour, A. R., B. J. Gogel, B. R. Cullis, and R. Thompson. 2006. Asreml User Guide Release 2.0. VSN International Ltd., Hempstead, HP1 1ES, UK.

Gutierrez-Gil, B., P. Wiener, G. R. Nute, D. Burton, J. L. Gill, J. D. Wood, and J. L. Williams. 2008. Detection of quantitative trait loci for meat quality traits in cattle. Anim. Genet. 39:51-61.

Itoh, N., S. Yonehara, A. Ishii, M. Yonehara, S. Mizushima, M. Sameshima, A. Hase, Y. Seto, and S. Nagata. 1991. The polypeptide encoded by the cdna for human cell surface antigen fas can mediate apoptosis. Cell 66:233-243.

JMGA. 1988. New Beef Carcass Grading Standards. Japan Meat Grading Association, Tokyo, Japan.

Johnson, D., A. Lanahan, C. R. Buck, A. Sehgal, C. Morgan, E. Mercer, M. Bothwell, and M. Chao. 1986. Expression and structure of the human NGF receptor. Cell 47:545-554.

Kim, N. K., D. Lim, S. H. Lee, Y. M. Cho, E. W. Park, C. S. Lee, B. S. Shin, T. H. Kim, and D. Yoon. 2011. Heat shock protein B1 and its regulator genes are negatively correlated with intramuscular fat content in the longissimus thoracis muscle of hanwoo (Korean Cattle) steers. J Agric. Food Chem. 59:56575664.

Lande, R. and R. Thompson. 1990. Efficiency of marker-assisted selection in the improvement of quantitative traits. Genetics 124:743-756.

Loetscher, H., Y. C. Pan, H. W. Lahm, R. Gentz, M. Brockhaus, H. Tabuchi, and W. Lesslauer. 1990. Molecular cloning and expression of the human $55 \mathrm{kd}$ tumor necrosis factor receptor. Cell 61:351-359.

Maj, A., J. Oprzadek, E. Dymnicki, and L. Zwierzchowski. 2006. Association of the polymorphism in the 5'-noncoding region of the bovine growth hormone receptor gene with meat production traits in Polish Black-and-White cattle. Meat Sci. 72:539-544.

Mallett, S., S. Fossum, and A. N. Barclay. 1990. Characterization of the MRC OX40 antigen of activated CD4 positive $\mathrm{T}$ lymphocytes--a molecule related to nerve growth factor receptor. EMBO J. 9:1063-1068.

Marques, E., J. D. Nkrumah, E. L. Sherman, and S. S. Moore. 2009. Polymorphisms in positional candidate genes on BTA14 and BTA26 affect carcass quality in beef cattle. J. Anim. Sci. 87:2475-2484.

Miller, S. A., D. D. Dykes, and H. F. Polesky. 1988. A simple salting out procedure for extracting DNA from human nucleated cells. Nucleic Acids Res. 16:1215. 
Nott, A., S. H. Meislin, and M. J. Moore. 2003. A quantitative analysis of intron effects on mammalian gene expression. RNA 9:607-617.

Oehm, A., I. Behrmann, W. Falk, M. Pawlita, G. Maier, C. Klas, M. Li-Weber, S. Richards, J. Dhein, and B. C. Trauth. 1992. Purification and molecular cloning of the APO-1 cell surface antigen, a member of the tumor necrosis factor/nerve growth factor receptor superfamily. Sequence identity with the Fas antigen. J. Biol. Chem. 267:10709-10715.

Otto, G., R. Roehe, H. Looft, L. Thoelking, P. W. Knap, M. F. Rothschild, G. S. Plastow, and E. Kalm. 2007. Associations of DNA markers with meat quality traits in pigs with emphasis on drip loss. Meat Sci. 75:185-195.

Palmiter, R. D., E. P. Sandgren, M. R. Avarbock, D. D. Allen, and R. L. Brinster. 1991. Heterologous introns can enhance expression of transgenes in mice. Proc. Natl. Acad. Sci. USA 88:478-482.

Quintans, B., V. Alvarez-Iglesias, A. Salas, C. Phillips, M. V. Lareu, and A. Carracedo. 2004. Typing of mitochondrial DNA coding region SNPs of forensic and anthropological interest using snapshot minisequencing. Forensic Sci. Int. 140:251-257.

Schall, T. J., M. Lewis, K. J. Koller, A. Lee, G. C. Rice, G. H. Wong, T. Gatanaga, G. A. Granger, R. Lentz, and H. Raab et al. 1990. Molecular cloning and expression of a receptor for human tumor necrosis factor. Cell 61:361-370.

Stamenkovic, I., E. A. Clark, and B. Seed. 1989. A B-lymphocyte activation molecule related to the nerve growth factor receptor and induced by cytokines in carcinomas. EMBO J. 8:14031410 .
Taniguchi, M., T. Utsugi, K. Oyama, H. Mannen, M. Kobayashi, Y. Tanabe, A. Ogino, and S. Tsuji. 2004. Genotype of stearoylCoA desaturase is associated with fatty acid composition in Japanese Black cattle. Mamm. Genome 15:142-148.

Trauth, B. C., C. Klas, A. M. Peters, S. Matzku, P. Moller, W. Falk, K. M. Debatin, and P. H. Krammer. 1989. Monoclonal antibody-mediated tumor regression by induction of apoptosis. Science 245:301-305.

USDA. 1989. Official United States Standards for Grades of Beef Carcases. Agric. Marketing Serv.:USDA, Washington, DC, USA.

Watanabe-Fukunaga, R., C. I. Brannan, N. Itoh, S. Yonehara, N. G. Copeland, N. A. Jenkins, and S. Nagata. 1992. The cDNA structure, expression, and chromosomal assignment of the mouse fas antigen. J. Immunol. 148:1274-1279.

Wood, J. D., G. R. Nute, G. A. J. Fursey, and A. Cuthbertson. 1995. The effect of cooking conditions on the eating quality of pork. Meat Sci. 40:127-135.

Yamada, T., S. Sasaki, S. Sukegawa, T. Miyake, T. Fujita, H. Kose, M. Morita, Y. Takahagi, H. Murakami, F. Morimatsu, and Y. Sasaki. 2009. Novel SNP in 5' flanking region of EDG1 associated with marbling in japanese Black beef cattle. Anim. Sci. J. 80:486-489.

Yonehara, S., A. Ishii, and M. Yonehara. 1989. A cell-killing monoclonal antibody (anti-Fas) to a cell surface antigen codownregulated with the receptor of tumor necrosis factor. J. Exp. Med. 169:1747-1756. 